\title{
Problematyka kwestionariusza do badań zmian funkcjonowania przedsiębiorstwa przemysłowego w okresie transformacji systemu gospodarowania
}

Jednym z najważniejszych problemów współczesnej geografii ekonomicznej

w Polsce jest badanie procesów transformacji gospodarki. Ponieważ przyjmuje się, że podstawowym elementem struktury gospodarczej jest przedsiębiorstwo przemysłowe, bardzo istotną kwestią badawczą jest jego zachowanie się w procesie transformacji systemu gospodarowania. System centralnego sterowania gospodarką, ograniczający w znacznym stopniu samodzielność przedsiębiorstw, nie sprzyjał koniecznej modernizacji asortymentu produkcji, struktur organizacyjnych, procesów produkcyjnych, wchłanianiu innowacji, dbałości o jakość produktów i in. (Zioło 1994). Nowe warunki gospodarowania, oparte na mechanizmie wolnego rynku, jak powszechnie wiadomo, zmusiły przedsiębiorstwa do samodzielnego budowania nowych strategii działania, określenia sposobu ich realizacji i pozyskania odpowiednich środków finansowania tych strategii, tj. przeprowadzenia restrukturyzacji. W efekcie, w przestrzeni przemysłowej przedsiębiorstwo może funkcjonować jako element nowo powstały, rozwijający się, stagnujący, regresywny czy - coraz częściej w nowych warunkach gospodarowania - likwidowany (Zioło 1988). Zarazem, wobec postępującego procesu globalizacji i perspektywy integracji struktur gospodarczych kraju ze strukturami europejskimi oraz otwarcia Polski na napływ obcego kapitału, ważnym zagadnieniem badawczym jest funkcjonowanie korporacji zagranicznych, jako jednych z głównych podmiotów biorących udział $\mathrm{w}$ transformacji gospodarki naszego kraju i restrukturyzacji poszczególnych przedsiębiorstw. Szczególnie istotne wydaje się pytanie, w jakim stopniu wejście inwestora zagranicznego wpływa na tempo i zakres procesu zmian w polskich przedsiębiorstwach.

Problematyka ta wymaga zastosowania odpowiednich metod badań. Jedną z nich jest metoda kwestionariusza, stosowana szeroko w geografii społeczno-ekonomicznej, w tym także w geografii przemysłu. Przedmiotem artykułu będzie więc problematyka terenowych badań geograficznych nad funkcjonowaniem przedsiębiorstw przy pomocy kwestionariusza. Dobrze skonstruowany, przejrzysty kwestionariusz jest nieodłączną pomocą w ćwiczeniach i badaniach przemysłu, szczególnie w sytuacji, gdy zdecydo- 
wana większość aspektów funkcjonowania przedsiębiorstw jest pomijana w oficjalnej sprawozdawczości statystycznej (Pakuła 1967).

W badaniach geograficznych, prowadzonych zwłaszcza w ośrodku krakowskim, opierano się na kwestionariuszu L. Pakuły (1967). Składa on się z 12 głównych problemów badawczych dotyczących:

1. zagadnień ogólnych,

2. lokalizacji zakładu,

3. historii rozwoju,

4. siły roboczej,

5. procesu mechanizacji,

6. zagadnień produkcji,

7. zaopatrzenia surowcowego,

8. zbytu produktów,

9. procesów technologicznych produkcji,

10. kosztów produkcji,

11. pozytywnego i negatywnego oddziaływania zakładu na okolice,

12. perspektyw rozwojowych.

Zaletą tego kwestionariusza jest układ problemowy, który ujmuje w sposób kompleksowy geograficzną problematykę badawczą każdego zakładu. Ponieważ jest to kwestionariusz o charakterze ogólnym, każdy ze szczegółowych kierunków badawczych wymaga oddzielnego, specyficznego opracowania, dostosowanego do jego celów i dominującej problematyki (Pakuła 1967).

Blisko 25 lat później niewielkiej modyfikacji tego kwestionariusza dokonał M. Troc (1991a). Zostały dodane pytania dotyczące: typu własności zakładu, innowacji w technologii wytwarzania i efektów finansowych z tym związanych, kosztów ponoszonych na ochronę środowiska i reklamę, wpływu zmian organizacyjnych pracy na koszty produkcji oraz $\mathrm{w}$ ostatniej grupie problemowej: zamiarów połączenia się lub wykup

innych zakładów. Nowszym opracowaniem jest drugi kwestionariusz M. Troca (1991b), służący do badania przedsiębiorstwa rolno-spożywczego. Autor zwrócił w nim uwagę na nowe problemy, pojawiające się w warunkach gospodarki rynkowej, tj. sposób prowadzenia reklamy, nowoczesność opakowań reklamujących wyrób i firmę, źródła finansowania nowych inwestycji w środki produkcji (np. poprzez leasing). Poszerzono także problematykę organizacji zbytu produktów o pytania dotyczące sprzedaży komisowej

i własnej sieci punktów sprzedaży (hurtowni). Nie uwzględniono w nim grupy problemów dotyczących perspektyw rozwojowych, natomiast problematyka oddziaływania zakładu na okolicę została zastąpiona pytaniami dotyczącymi oddziaływania na rolnicze zaplecze, ze względu na specyfikę branży badanego zakładu.

Nieco innym przykładem jest kwestionariusz opracowany przez M. Rileya i S. Pączkę (Pączka 1994), służący ustaleniu ogólnych zmian struktury przemysłu włókienniczego w Łodzi na przełomie lat osiemdziesiątych i dziewięćdziesiątych. Cechą charakterystyczną tego kwestionariusza jest wyraźny podział na dwa okresy funkcjonowania przedsiębiorstwa, do 1989 r. i po 1989 r., czyli w ramach gospodarki centralnie sterowanej i w nowych warunkach gospodarowania. Kwestionariusz złożony jest z 6 zasadniczych działów dotyczących: 
1) zagadnień ogólnych,

2) dostaw materiałów,

3) produkcji,

4) zatrudnienia,

5) rynków zbytu,

6) perspektyw rozwoju.

Zmieniające się warunki gospodarowania wymuszają nowe procesy dostosowawcze przedsiębiorstw, które uwzględniać muszą także przyszłe tendencje integracyjne $\mathrm{z}$ Europą Zachodnią oraz globalny proces rozwoju gospodarczego. Przy podejmowaniu problematyki zmian funkcjonowania przedsiębiorstw potrzebne jest więc zaakcentowanie innych zagadnień badawczych i tym samym stworzenie nowego kwestionariusza do badań. Założono, że proces zmian funkcjonowania przedsiębiorstwa ma charakter dynamiczny oraz że ciągłym zmianom podlegają także warunki otoczenia, dlatego dane zbierane na jego podstawie powinny obejmować przynajmniej 2 przekroje czasowe (ryc.1):

1) okres funkcjonowania w ramach gospodarki centralnie sterowanej,

2) etap funkcjonowania po zmianie systemu gospodarowania.

\begin{tabular}{|c|c|c|c|}
\hline Lata gospodarki centralnie sterowanej & \multicolumn{3}{|c|}{ Lata transformacji systemu gospodarowania } \\
\hline 1 & $2 \mathrm{a}$ & $2 \mathrm{~b}$ & $2 \mathrm{c}$ \\
\hline \multicolumn{4}{|c|}{$1989 \mathrm{r}}$. \\
\hline
\end{tabular}

Ryc. 1. Etapy funkcjonowania przedsiębiorstwa

Źródło: oprac. własne

Ze względu na fakt, iż istotny wpływ na procesy restrukturyzacji w przedsiębiorstwie mógł mieć proces prywatyzacji i pojawienie się inwestora strategicznego (w szczególności kapitału zagranicznego) okres drugi, tj. funkcjonowania w ramach nowego systemu gospodarowania, należałoby podzielić na 3 podokresy:

a) okres od 1989 r. do momentu prywatyzacji,

b) okres od prywatyzacji do momentu przejęcia przedsiębiorstwa przez inwestora,

c) okres po przejęciu kontroli nad funkcjonowaniem przedsiębiorstwa przez inwestora.

Należy zaznaczyć, że proces prywatyzacji może być bezpośrednio związany z przejęciem przedsiębiorstwa przez inwestora strategicznego. Jednak na podstawie przeprowadzonych dotychczas badań można stwierdzić, że bardzo często przedsiębiorstwo wcześniej sprywatyzowane w późniejszym okresie znajduje inwestora strategicznego. Wyodrębnienie tych podokresów pozwoli na ocenę, jak duży wpływ na przyspieszenie (bądź w niektórych przypadkach spowolnienie) procesu restrukturyzacji mają zmiany struktury własnościowej i pojawienie się inwestora strategicznego.

Prezentowany poniżej kwestionariusz, opracowany na podstawie kwestionariuszy L. Pakuły i M. Troca, składa się z 14 grup tematycznych. Uzupełniono go dwoma zupełnie nowymi grupami problemów dotyczących inwestora strategicznego. W omówie- 
niu kwestionariusza zwrócono szczególną uwagę na te części kwestionariusza, które dotyczą przede wszystkim nowych aspektów funkcjonowania przedsiębiorstwa.

W ramach zagadnień ogólnych (p. 1) na uwagę zasługuje kwestia zmiany nazwy przedsiębiorstwa, tj. czy inwestor strategiczny (zagraniczny) utrzymał dotychczasową, czy może nadał nową nazwę przedsiębiorstwu (najczęściej swoją własną). Drugim ważnym zagadnieniem jest struktura kapitału akcyjnego i zarazem odpowiedź na pytanie, czy inwestor dąży do zwiększenia udziałów np. poprzez odkupienie akcji od pracowników. W okresie prowadzonej prywatyzacji i reprywatyzacji problematykę własnościową można w uzasadnionych przypadkach poszerzyć o kwestię stanu prawnego nieruchomości i gruntów na podstawie wpisów do ksiąg wieczystych.

W zakresie lokalizacji przedsiębiorstwa (p. 2) obok kwestii, które wystapiły w kwestionariuszach L. Pakuły i M. Troca, tj. położenia fizjograficznego, w stosunku do centrum miasta i infrastruktury transportowej, zwrócono uwagę na fakt położenia firmy w Specjalnej Strefie Ekonomicznej i czy w związku z tym inwestor otrzymał zwolnienia podatkowe. Interesujące może być także zagadnienie, czy korzystne jest położenie przedsiębiorstwa $\mathrm{w}$ stosunku do kooperantów i konkurencji.

Punkt 3 dotyczy historii przedsiębiorstwa, w tym czynników lokalizacji oraz etapów jego rozwoju.

Ważna grupę zagadnień (p. 4) stanowi charakterystyka inwestora strategicznego (w szczególności, gdy jest to koncern zagraniczny), tj. kraj pochodzenia i siedziba zarządu, struktura organizacyjna, rozmieszczenie, struktura wielkościowa i asortyment produkcji zakładów na świecie, oraz charakterystyka powiązań inwestora z badanym przedsiębiorstwem, tj. inwestycji (p. 5), obejmująca m.in. motywy oraz wielkość zainwestowanego kapitału, podjęte zobowiązania (w tym docelowa wielkość inwestycji, gwarancje zatrudnienia, przywileje socjalne), a także zmiany w strukturze organizacyjnej (dostosowanie jej do struktury koncernu).

W ramach problematyki stosunków pracy (p. 6), oprócz wystepujących w omawianych kwestionariuszach pytań dotyczących zmian wielkości i struktury zatrudnienia w poszczególnych okresach, ważne wydaje się pytanie, w jakim zakresie (tj. do jakiego szczebla) stanowiska kierownicze zostały przejęte przez przedstawicieli koncernu i czy dotychczasowa kadra zarządzająca miała szansę pozostać i wykazać się na swoich stanowiskach. Istotny problem stanowią także zwolnienia grupowe oraz nowe przyjęcia do pracy. Nie badanym do tej pory problemem była kwestia wysokości płac na poszczególnych stanowiskach oraz zmian w systemie zarządzania i szkoleń pracowników. W warunkach silnych nacisków politycznych załóg, szczególnie w dużych przedsiębiorstwach, słuszne wydaje się poruszenie problemu przynależności do związków zawodowych oraz próba oceny siły wpływu tych zwiazków na procesy restrukturyzacji.

W zakresie wielkości i asortymentu produkcji (p. 7) zwrócono uwagę na kwestię, $\mathrm{w}$ jakim stopniu inwestor narzucił własny, a w jakim utrzymał dotychczasowy asortyment produkcji i - co za tym idzie - jakie zmiany nastapiły w procesie technologicznym (p. 8). Istotne obecnie stają się pytania dotyczące prac badawczo-rozwojowych nad nowymi technologiami i produktami: czy są one przynajmniej w części prowadzone i rozwijane w badanym przedsiębiorstwie, czy może importowane $\mathrm{z}$ ośrodków badawczo-rozwojowych korporacji.

Zmiana asortymentu i technologii produkcji mogła spowodować całkowitą zmiane w zakresie źródeł zaopatrzenia materiałowego (p. 9), ważny problem stanowi więc 
kwestia zmiany kierunku dostaw, w szczególności postawiono pytanie, czy wprowadzony proces produkcyjny polega na montażu z półfabrykatów (części) wyprodukowanych w innych zakładach koncernu.

W ramach problematyki zbytu produktów (p. 10) uwzględniono problematykę udostępnienia przedsiębiorstwu rynków zbytu (w tym zagranicznych) przez inwestora. Jest to szczególnie istotne $\mathrm{z}$ powodu załamania się dotychczasowych, najczęściej wschodnich, rynków zbytu. W obrębie tego problemu należy zwrócić uwagę, czy cel inwestora nie jest dokładnie odwrotny, tj. polegający na przejęciu dotychczasowych rynków zbytu przedsiębiorstwa czy - w skrajnym przypadku - na wyeliminowaniu konkurencji. Ważnym problemem są także zmiany w zakresie techniki i organizacji sprzedaży, polegające na tworzeniu i rozbudowywaniu nowych działów oraz wykorzystaniu technik reklamowych.

W procesie transformacji systemu gospodarowania istotne zmiany następują w strukturze kosztów przedsiębiorstwa (p. 11). Szczególnie uważnie powinna być śledzona zmiana wielkości kosztów amortyzacji, świadczących o wysokości rzeczywistych nakładów inwestycyjnych (w środki produkcji). Istotnym problemem badawczym jest także tendencja do likwidacji obciążeń socjalnych, polegająca na pozbywaniu się np. ośrodków wczasowych, przychodni i szkół przyzakładowych, świetlic, stołówek itp. oraz wzrost kosztów usług obcych poprzez "wyprowadzanie” niektórych czynności obsługi poza strukturę przedsiębiorstwa. W gospodarce rynkowej coraz ważniejsze stają się również koszty organizacji i utrzymania sieci sprzedaży (np. poprzez tworzenie własnych sieci hurtowni czy sklepów firmowych) oraz koszty ponoszone na reklamę. Wzrasta także znaczenie kosztów operacji finansowych (np. odsetek od zaciaganych kredytów). Zjawiska te uwzględnione zostały w p. 11.8 i 11.9.

Proces restrukturyzacji przedsiębiorstwa powinien przyczynić się do wzrostu rentowności produkcji (p. 12). W szczególności istotne wydaje się pytanie, jak od momentu przejęcia przedsiębiorstwa przez inwestora kształtowały się wyniki finansowe.

Ważnym problemem jest także wpływ inwestycji na rozwój lokalny, np. na rozwój infrastruktury, rynek pracy (p. 13) oraz ocena dotychczasowej restrukturyzacji i perspektywy rozwoju przedsiębiorstwa (p. 14), m.in. dalsze inwestycje w środki produkcji, zmiany w zatrudnieniu, wchodzenie w spółki czy wykup innych przedsiębiorstw, wejście na giełdę, kierunki dalszej integracji ze strukturą organizacyjną koncernu, przewidywane wyniki finansowe itd.

Przedstawiony kwestionariusz obejmuje różnorakie aspekty funkcjonowania przedsiębiorstwa i może stanowić podstawę do tworzenia kwestionariuszy szczegółowych, obejmujących zagadnienia dotyczące wybranych obszarów działalności przedsiębiorstwa i jego różnorodnych zmian. W doborze problematyki badawczej należy sobie zdawać jednocześnie sprawę z faktu ograniczonej dostępności do tak szerokich i szczegółowych danych, ze względu na tajemnicę handlową. 


\section{Kwestionariusz do badań zmian funkcjonowania przedsiębiorstwa przemysłowe- go}

w okresie transformacji systemu gospodarowania

\section{Zagadnienia ogólne}

1.1. Nazwa przedsiębiorstwa (zmiany nazwy, w tym po prywatyzacji i wejściu inwestora strategicznego)

1.2. Organizacja przedsiębiorstwa (liczba zakładów, filii, siedziba zarządu)

1.3. Przynależność do sekcji/działu/grupy przemysłu (wg EKD)

1.4.Typ własności (np. spółka z o.o. lub akcyjna - udziały \%, w tym udziały inwestora)

1.5. Znaczenie produkcyjne - ogólnie (lokalne, regionalne, ogólnopolskie, światowe)

2. Lokalizacja przedsiębiorstwa

2.1. Adres (przynależność administracyjna)

2.2. Położenie w stosunku do centrum miasta (peryferyjne, w centrum itd.)

2.3. Położenie fizjograficzne

2.3.1. rzeźba terenu, warunki geologiczne, typy gleb

2.3.2. w stosunku do bogactw naturalnych (odległość od surowca, jeśli jest to istotne)

2.3.3. w stosunku do sieci rzecznej, zbiorników wodnych itp. (jeśli potrzebuje dużo wody)

2.4. Położenie w stosunku do infrastruktury transportowej (drogi, koleje, gazociagi, linie energetyczne itp.)

2.5. Lokalizacja w stosunku do innych przedsiębiorstw (kooperantów i konkurencji)

2.6. Położenie w Specjalnej Strefie Ekonomicznej. Jakie z tego tytułu przedsiębiorstwo ma przywileje?

3. Proces kształtowania się przedsiębiorstwa w rozwoju historycznym

3.1. Czynniki lokalizacji i rozwoju (w tym rok założenia)

3.2. Etapy rozwoju przedsiębiorstwa

4. Charakterystyka inwestora strategicznego (w tym zagranicznego)

4.1. Nazwa inwestora(-ów),

4.2. Kraj pochodzenia w przypadku inwestora zagranicznego (ew. międzynarodowy)

4.3. Siedziba zarządu koncernu

4.4. Struktura organizacyjna koncernu (na świecie)

4.5. Rozmieszczenie i struktura wielkościowa zakładów koncernu na świecie (wg liczby zatrudnionych lub wysokości obrotów) oraz ich asortyment produkcji

5. Powiązania inwestora strategicznego (zagranicznego) z przedsiębiorstwem

5.1. Rok zainwestowania kapitału (przejęcia kontroli nad przedsiębiorstwem)

5.2. Czynniki (motywy) wejścia kapitału (atrakcyjność przedsiębiorstwa dla kapitału zagranicznego)

5.3. Wielkość zainwestowanego kapitału (w tym na zakup akcji i rzeczywiste inwestycje w produkcję)

5.4. Zobowiązania inwestycyjne (m.in. docelowa wielkość inwestycji, gwarancje zatrudnienia, socjalne itp.)

5.5. Zmiany w strukturze organizacyjnej przedsiębiorstwa (dostosowanie do struktury koncernu)

6. Zagadnienia stosunków pracy

6.1. Zmiany w poziomie zatrudnienia ( $w$ tym po zakończeniu okresu ewentualnej gwarancji zatrudnienia)

6.2. Zwolnienia grupowe 
6.3. Nowe przyjęcia do pracy (na jakie stanowiska)

6.4. Zmiany w strukturach kierowniczych przedsiębiorstwa (jakie stanowiska zostały przejęte przez pracowników inwestora)

6.5. Zmiany stosunku pracowników nieprodukcyjnych (umysłowych) do bezpośrednio produkcyjnych

6.6. Zmiany w wykształceniu pracowników

6.7. Zmiany wysokości płac (średnia na danych stanowiskach, ew. w stosunku do innych przedsiębiorstw lub średniej krajowej)

6.8. Miejsce zamieszkania pracowników (czy przedsiębiorstwo ponosiło i nadal ponosi koszty dowozu?)

6.9. Zmiany w systemie szkoleń pracowników oraz metodach zarzadzania

6.10. Przynależność pracowników do związków zawodowych (udział \% w stosunku do ogółu zatrudnionych)

7. Wielkość i asortyment produkcji

7.1. Zmiany profilu produkcji przedsiębiorstwa na podstawie zmian wartości produkcji rocznej wg asortymentu

7.2. Zmiany wielkości produkcji (w jednostkach produkowanego asortymentu)

7.3. Zmiany wartości produkcji sprzedanej w zł

7.4. Dostosowanie produkowanego asortymentu do globalnej strategii inwestora

8. Proces technologiczny

8.1. Etapy procesu technologicznego - droga surowca do uzyskania postaci użytecznej (od stadium przygotowawczego, przez proces właściwy do stadium końcowego pakowania)

8.2. Mechanizacja procesu produkcji na poszczególnych etapach, komputeryzacja i inne innowacje w technologii wytwarzania

8.3. Park maszynowy, stopień zużycia maszyn i urządzeń (nowe inwestycje)

8.4. Działalność badawczo-rozwojowa (czy jest prowadzona i w jakim zakresie)

8.5. Transport wewnatrz zakładów produkcyjnych (ew. pomiędzy nimi)

9. Zaopatrzenie w materiały (surowiec) do produkcji

9.1. Zmiany źródeł zaopatrzenia materiałowego (miejsce, wartość lub udział \%)

9.2. Własne źródła surowca, ich wielkość (udział \%)

9.3. Zaopatrzenie przedsiębiorstwa w półfabrykaty. Czy koncern (inwestor) dostarcza własne półfabrykaty do produkcji? Jaki stanowią udział w wartości ogółu dostaw?

9.4. Zaopatrzenie w źródła energii i wodę (jeśli są ważnym czynnikiem produkcji)

9.5. Zaopatrzenie w opakowania

9.6. Zaopatrzenie w maszyny i urządzenia do produkcji (skąd są sprowadzane)

10. Zbyt produkcji

10.1. Zmiany w wielkości i wartości zbytu wg miejscowości (regionów, województw itp.)

10.2. Struktura przestrzenna rynków zbytu (lokalny, regionalny, ogólnokrajowy itd.)

10.3. Przyczyny stałości lub zmienności kierunków zbytu

10.4. Zmiany wartości eksportu (udział \% w całkowitej sprzedaży)

10.5. Zmiany kierunków eksportu (wg państw)

10.6. Rentowność sprzedaży eksportowej w stosunku do sprzedaży w kraju - przyczyny zróżnicowania tej rentowności

10.7. Transport towaru do odbiorców

10.8. Zmiany w zakresie techniki i organizacji sprzedaży - dział marketingu, nowe formy reklamy. Czy są trudności z pozyskania specjalistów od marketingu?

10.9. Czy pozyskanie inwestora strategicznego otwarło drogę ku nowym (w tym zagranicznym) rynkom zbytu (np. poprzez udostępnienie własnej sieci sprzedaży) 
11. Zmiany w strukturze kosztów produkcji

11.1. Zużycie energii i materiałów

11.2. Amortyzacja środków trwałych

11.3. Podatki i opłaty

11.4. Wynagrodzenia i świadczenia pracowników

11.5. Inne koszty socjalne (np. utrzymanie własnych ośrodków wczasowych, dowóz pracowników)

11.6. Usługi obce

11.7. Koszty ponoszone na ochronę środowiska (w tym np. kary za zanieczyszczenia, koszt utrzymania urządzeń służących ochronie środowiska)

11.8. Koszty organizacji i utrzymania sieci sprzedaży oraz transportu towaru do klienta (jeśli przedsiębiorstwo samo dostarcza towar)

11.9. Koszty pozostałe ( $w$ tym m.in. nakłady na reklamę, prace badawczo-roz-wojowe, koszty kredytów, leasingu itd.)

12. Rentowność produkcji - wyniki finansowe

12.1. Zmiany w rentowności produkcji (zysk/strata)

12.2. Zwolnienia podatkowe (jeśli są na jakiej podstawie)

12.3. Efekty finansowe zwiazane z innowacjami technicznymi (np. komputeryzacja)

12.4. Wpływ zmiany organizacji pracy (zatrudnienia) na wyniki finansowe

13. Pozytywny i negatywny wpływ na okolice

13.1. Przykłady korzystnego oddziaływania na miasto lub okolicę (np. rozwój inwestycji lokalnych, komunikacji)

13.2. Wpływ na stopę bezrobocia (czy zmiany zatrudnienia przyczyniły się do jego zwiększenia czy zmniejszenia)

13.3. Wpływ na rozwój rolnictwa (jeśli branża rolno-spożywcza)

13.4. W pływ na inne przedsiębiorstwa (kooperantów, podwykonawców) w okolicy

13.5. Przekształcenie środowiska geograficznego w zwiazku z rozbudową przedsiębiorstwa (np. zajmowanie nowych terenów, powstanie form antropogenicznych)

13.6. Zanieczyszczenie środowiska (zmiany udziału przedsiębiorstwa w ogólnej emisji zanieczyszczeń w okolicy)

13.7. Rekultywacja terenów zniszczonych pod wpływem działalności przemysłowej przedsiębiorstwa

14. Ocena dotychczasowego procesu zmian oraz perspektywy rozwoju przedsiębiorstwa

14.1. Ocena procesu restrukturyzacji oraz wpływu inwestora strategicznego na funkcjonowanie przedsiębiorstwa (rozwój produkcji, rozszerzenie rynków zbytu itd.) w świetle wypowiedzi kadry zarządzającej oraz pracowników

14.2. Terenowe możliwości rozbudowy poszczególnych zakładów przedsiębiorstwa (czy istnieje taka potrzeba?)

14.3. Zamiary połączenia się z innymi (lub rozdzielenia), wejścia w spółki, wykup innych przedsiębiorstw itp.

14.4. Kierunki inwestowania i ich uzasadnienie

14.5. Wejście na giełdy papierów wartościowych.

14.6. Dalsze zmiany w dostosowaniu struktury organizacyjnej do struktury koncernu i w organizacji pracy

14.7. Przebudowa infrastruktury technicznej

14.8. Możliwości w zakresie pozyskania nowych rynków zbytu.

14.9. Przewidywane wyniki finansowe 


\section{Literatura}

Pakuła L., 1967, Uwagi o prowadzeniu ćwiczeń terenowych z geografii przemystu, [w:] Wybrane zagadnienia z metodyki ćwiczeń terenowych z geografii ekonomicznej, Prace z dydaktyki szkoły wyższej, z. 4, WSP w Krakowie

Pączka S., 1994, Badania dotyczace funkcjonowania przedsiębiorstw przemystowych $w$ zmieniajacych się warunkach gospodarowania w Polsce, [w:] Funkcjonowanie przedsiębiorstw przemystowych $w$ zmieniajacych się warunkach gospodarowania, red. Z. Zioło, COMSN, Komisja Geografii Przemysłu PTG, Wydawnictwo Naukowe WSP, Kraków-Warszawa

Troc M., 1991a, Ćwiczenia z geografii przemysłu, Wydawnictwo Naukowe WSP, Kraków

Troc M., 1991b, Kwestionariusz do badania zaktadu przemystu rolno-spożywczego, [w:] Problemy przemystu rolno-spożywczego w badaniach geograficznych, red. Z. Zioło, COMSN, Komisja Geografii Przemysłu PTG, Wydawnictwo Naukowe WSP, Kraków-Warszawa

Zioło Z., 1988, Funkcjonowanie i rozwój przedsiębiorstwa przemysłowego w przestrzeni geograficznej, red. Z. Zioło, Materiały i Sprawozdania COMSN nr 16, Wydawnictwo Naukowe WSP, Kraków

Zioło Z., 1994, Zmiany otoczenia przedsiębiorstw przemysłowych w nowych warunkach gospodarowania, [w:] Funkcjonowanie przedsiębiorstw przemystowych $w$ zmieniajacych sie warunkach gospodarowania, red. Z. Zioło, COMSN, Komisja Geografii Przemysłu PTG, Wydawnictwo Naukowe WSP, Kraków-Warszawa 